\title{
The Legal Framework of Shareholders Activism in Malaysia in Promoting Environmental, Sustainability and Governance (ESG)
}

\author{
Muhammad Umar Abdul Razak', Wan Mohd Zulhafiz Wan Zahari², \\ Abdul Mu'iz Abdul Razak', Azlan Roni ${ }^{4}$, Nurul Ula Ulya ${ }^{5}$ \\ ${ }^{1}$ Faculty of Law, Universiti Teknologi MARA, Shah Alam, Malaysia \\ ${ }^{2}$ Ahmad Ibrahim Kuliyyah of Laws, Islamic International University, Gombak, Malaysia \\ ${ }^{3}$ Faculty of Law, Universiti Teknologi MARA, Shah Alam, Malaysia \\ ${ }^{4}$ Messrs Roni \& Co, Malaysia \\ 5 Universitas Brawijaya, Malang, Indonesia
}

umar0001@uitm.edu.my, wzulhafiz@iium.edu.my, abdmuiz@uitm.edu.my, roni.azlan@gmail.com, lialea65@gmail.com Tel: +60126541047

\begin{abstract}
Environmental, sustainability and governance (ESG) are components in a corporate sustainability reporting. This paper analysed the legal framework in Malaysia to promote ESG. It employed library-based doctrinal study and comparative legal analysis in a descriptive, analytic and prescriptive manner. Despite the availability of legal framework, the shareholder's proposal is mostly turned down in general meeting. Nevertheless, there is a growing trend of shareholders activist advocating ESG-related matters. This paper contributes to the discussion on strengthening the framework to promote ESG reporting practices in Malaysia.
\end{abstract}

Keywords: ESG; shareholders activism, shareholder's proposal,

eISSN: 2398-42870 2021. The Authors. Published for AMER ABRA cE-Bs by e-International Publishing House, Ltd., UK. This is an open access article under the CC BYNC-ND license (http://creativecommons.org/licenses/by-nc-nd/4.0). Peer-review under responsibility of AMER (Association of Malaysian Environment-Behaviour Researchers), ABRA (Association of Behavioural Researchers on Asians/Africans/Arabians) and CE-Bs (Centre for Environment-Behaviour Studies), Faculty of Architecture, Planning \& Surveying, Universiti Teknologi MARA, Malaysia.

DOI: https://doi.org/10.21834/ebpj.v6i16.2663

\subsection{Introduction}

Environmental, sustainability and governance (ESG) are elements in a corporate sustainability practice that covers aspects of (i) environmental issues such as resource scarcity and climate change; (ii) social topics such as a company's talent management, labour practices, data security and product safety; and (iii) governance issues such as business ethics, executive pay, and board diversity (PWC, 2020a).

Shareholder activism comes in several forms, including participating privately in a discussion about particular issues with a corporation, holding a consultation to replace members of the board of directors of a company and openly agitating for a company to undertake a transaction. It is a broad phenomenon and corresponds to the various actions undertaken by investors to influence corporate management and board to make corporations change in corporate social responsibility ("CSR") or improve their financial outcomes (Chung \& Talaulicar, 2010). It includes actively promoting ESG in the company's agendas via shareholder's proposal. Such a proposal process creates "on the record" statements at a company's annual meeting, with the ability to generate shareholder votes and the

eISSN: 2398-4287@ 2021. The Authors. Published for AMER ABRA cE-Bs by e-International Publishing House, Ltd., UK. This is an open access article under the CC BYNC-ND license (http://creativecommons.org/licenses/by-nc-nd/4.0). Peer-review under responsibility of AMER (Association of Malaysian Environment-Behaviour Researchers), ABRA (Association of Behavioural Researchers on Asians/Africans/Arabians) and cE-Bs (Centre for Environment-Behaviour Studies), Faculty of Architecture, Planning \& Surveying, Universiti Teknologi MARA, Malaysia.

DOI: https://doi.org/10.21834/ebpj.v6i16.2663 
potential to change actual corporate policy (Kalodimos \& Leavitt, 2020). It could be a communication tool to express concerns to the board in various matters, including those usually associated with concentrated ownership corporations, such as questionable business decisions and excessive executive remuneration that could affect the minority shareholders to a certain extent. Indeed, some shareholders desire to influence companies to adopt socially responsible practices and policies, particularly ESG issues.

ESG reflects a conceptual framework to boost risk-adjusted returns through asset groups and investment strategies. ESG reporting is one of the measures to attain transparency about a company's respective performance and means of communication to stakeholders such as shareholders or investors. It can also help to make enterprises more accountable strategically and instrumentally (Chan \& Welford, 2005). The shareholders could do more than just being passive investor by raising ESG issues to the board. MSWG proposed a more proactive role in raising environment-cum-governance matters at the annual general meetings (AGMs) of relevant public companies (MSWG, 2020). For example, BlackRock, one of the largest institutional investors who own insignificant shares in Top Glove Bhd, proposed a motion against independent directors' re-election for its failure to handle the migrant workers' health and safety. However, most shareholders voted down the motion at the annual general meeting (Rahman, 2021). The democratic principle in a corporation has somehow hindered the shareholder activists from querying ESG. This instance showed that despite having the legal framework for shareholders proposal to raise awareness about ESG, it can still be voted down by the majority due to the small shareholding percentage. The methodology employed in this paper will be a library-based doctrinal study and comparative legal analysis, which will be carried out in a descriptive, analytic and prescriptive manner. In this regard, this paper analyses the Malaysian Companies Act 2016 and the Indonesian Law No 40 of 2007, decided cases and journal articles and determined the factors that are hindering shareholders proposal in promoting ESG. The doctrinal legal method is problem-solving in nature, and it is the most wellunderstood of the legal research methods due to its links with the problem-solving approach at the heart of legal instruction (Dent, 2017). This paper's limitation is that it is challenging to obtain verified legal texts from Indonesia in English as their official legal language is Indonesian.

\subsection{Literature Review}

The agency theory propounded that the managers are having power over the firm's resources, and with this vast discretion, the managers are free to pursue activities that can directly expropriate wealth from other stakeholders and the firm. Shareholder activism is one way to address executive mismanagement and to ensure directors' accountability (Mohd-Sulaiman \& Hassan, 2017). As principals, the shareholders should educate directors on how to wield their power and perform their duties beyond maximising profit, including advancing social concerns (Fairfax, 2019). There is a growing trend around the world where the shareholders' proposal is a tool to pursue ESG agendas (Aquila, 2019), but ESG has little impact on firms' profitability (Atan et al., 2018). Previous researchers mostly discussed the effectiveness of shareholders' proposal to advance the ESG agenda (Aslan, 2020; T. C. W. Lin, 2018) but rarely discuss the legal barriers that hindered it. (Y. H. Lin, 2019)(Y. H. Lin, 2019)(Y. H. Lin, 2019)Therefore, shareholders should use the power of ownership to stage movements that can influence companies to develop and adopt successful strategies and high standards of governance (Samat \& Ali, 2019). In a conflict, shareholders activist exercises their rights by including putting forward the shareholder proposal. However, expanding shareholders' power in management is viewed with caution as it could inefficient for the board to accommodate activist shareholders that lead to conflicts (Baileadge, 2006). The annual general meeting (AGM) serves as the legal decision-making of shareholders regarding decisions that are outside the board's discretion. However, a successful shareholders proposal related to ESG in AGM is rare because common law, in general, does not favour the idea that shareholders should interfere with the board's unfettered jurisdiction. The shareholder activist was always at the directors' mercy when they confronted the majority shareholders in the general meeting in Top Glove above.

\subsection{Shareholders Activism in Malaysia}

The debate between the division of powers between the board of director and the general meeting continues because of the common law position that shareholders should not interfere with the board's jurisdiction in managing the company. Under the common law, the division of power can be seen in Automatic Self-Cleansing Filter Syndicate Co Ltd v Cunninghame [1906] 2 Ch 34, where the court favoured the directors' sole discretion to dispose of the company's assets because it was within its company's constitution. In the case of Australian Centre for Corporate Responsibility v Commonwealth Bank of Australia [2015] FCA 785, the court decided that the shareholder's proposal to require the directors to provide a report on greenhouse emission was validly rejected because it encroached on the board's jurisdiction to make business decisions. These cases reflect the dilemma faced by the minority shareholders who intended to exert influence on the company's direction but was turned down due to their minority shareholding. The shareholders wanted to be more than just an investor by promoting ESG-related proposal, but the legal threshold to pursue is restricted.

Section 211 of the Malaysian Companies Act ("CA 2016") provides that the board's management power lies in the board of directors ("BOD"). In this unitary board model, the executive and non-executive board is the organisation's highest governing body (Nahar Abdullah, 2004). Despite the strict adherence to the common law position on this division of powers, CA 2016 does provide that certain decisions or transactions can only be made or carried out with shareholders' approval. Generally, it confers the following rights to vote and speak, among others:

- Attend, participate and speak at a meeting; or

- Vote on a show of hands on any resolution of the company; or 
- $\quad$ One vote for each share on a poll on any resolution of the company;

The meeting of shareholders will pass resolutions upon approval or rejection on some issues. This resolution can be either an ordinary resolution or a special resolution. Section 291 defines that ordinary resolution as a resolution passed with a simple majority or more than half of the members (51\%). Meanwhile, Section 291 defines a special resolution as a resolution passed by a majority not less than $75 \%$ of members entitled to vote in person or by proxy at a meeting or by written resolution. A written resolution is a resolution that was passed without holding a physical meeting, which is only available for a private company. The problem is, shareholder activists who wish to advance their ESG agendas but who own less than a significant number of shares in the company cannot exert any influence in the general meetings. Furthermore, only members who own (individually or collectively) at least $10 \%$ voting power in the company may convene a general meeting. They also could request the directors to convene a meeting on their behalf under Section 311, where the matters or agenda to be considered are those proposed by the members. Section 323 also that members of a public company have the power to request directors to prepare and attach to the notice of a resolution a 1,000-word statement explaining the matter referred to in the proposed or resolution or other business to be dealt with at the meeting upon receiving a request from members. However, for the shareholders to do so, they must first incur the expenses involved in circulating this notice, and minority shareholders may find this costly.

Shareholder activism is further empowered by the inclusion of Section 195, where it provides for shareholder's power to review the board. This is a new provision in CA 2016 that upholds the shareholder's primacy rule by requiring the chairperson to give any shareholders the opportunity to question, discuss, comment or make recommendations on the management of the company. However, it will be binding if the recommendation is in the best interest of the company and the right to make such recommendation is provided in the company's constitution. Alternatively, such recommendation can be binding if it is passed with a supermajority, which is by special resolution. This provision appears ideal for shareholder activists to advance the ESG agenda, but it may not be practical. This is because decided case laws held that the meaning of 'best interest of the company' shall lie within the board and not the shareholders. Unless and until ESG-related is included in the company's constitution, the shareholder activist may not be successful in advancing ESG-related agendas in AGM.

Having said the above, most shareholders proposals in Malaysia revolve around the board's management and policies, like executive remunerations or poor financial performance. Unfortunately, the trend of discussing ESG as a part of corporate governance is still low, and most public-listed companies in Malaysia are not prepared to embrace ESG reporting (MSWG, 2020). A report by PWC revealed that $73 \%$ of Malaysian companies mentioned the Sustainable Development Goals (SDGs) in their reporting, but only $20 \%$ had included SDGs in their published business strategy (PWC, 2020b). This supports the notion that companies with ESG information may not necessarily perform any better than those with less ESG information (Atan et al., 2018).

\subsection{Shareholders Activism in Indonesia}

Shareholder activism is not recognised in Indonesia. Unlike the unitary board system, Indonesian corporate organisation is a dual-tier board system that is divided into three components, namely, General Meeting of Shareholders ("GOM"), Board of Directors ("BOD") and Board of Commissioners ("BOC"). The board makes each executive decision of Directors, but they are monitored by a Board of Commissioners, who are nominated and elected in a General Meeting of Shareholders ("GMS"). However, Indonesian company laws provide avenues for minority shareholders to provide a check and balance mechanism. For, e.g., Rule No. IX.E.1 of 2008 requires any conflict-of-interest transactions require approval from disinterested shareholders. Besides, shareholders who represent $10 \%$ of the total number of shares with valid voting rights can file a lawsuit against the BOD or BOC who have caused losses to the company due to their negligence (Eddymurthy \& Fakhry, 2020). However, in the context of shareholders proposal in the general meeting, especially to promote the ESG, such an opportunity is still unclear.

The Indonesian National Survey Institute surveyed in 2019 to determine the awareness level and perception of social environment and governance among business in Indonesia. It was revealed that $40.9 \%$ of respondents had integrated ESG in its reporting, but it may not be comprehensive, and $24.6 \%$ are still doing it partially (Survei Nasional: Environmental Social Governance (ESG), 2019). Many respondents (66.1\%) think that ESG is essential because it supports the company's sustainability. It can be concluded that the awareness among Indonesian corporations is still low because only $15.8 \%$ of respondents have specific guidelines for making an investment decision. The preamble to the Law No. 40 of 2007 Concerning Limited Liability Company states that the national economy shall be implemented based on economic democracy with the principles of community, fair efficiency, sustainability, environmental awareness, independence, and safeguards for balanced progress and national economic unity (Law No. 40 of 2007 Concerning Limited Liability Company, 2007). It also requires the BOD to include in its annual report the implementation of social and environmental responsibility, which refers to the company's commitment to participate in sustainable economic development and increase the quality of life and the environment. In addition to that, Law No. 25 of 2007 states that the objective of an investment company shall, among others, is improving sustainable economic development and improving the prosperity of the community to develop a sustainable national economy based on economic democracy (Law No 25 of 2007 Concerning Investment, 2007). These laws emphasise the significance of corporate social responsibility. The corporation shall be responsible for creating a harmonious, balanced relationship in accordance with the acceptable environment, value, norms, and culture of the local community. 


\subsection{Discussion}

Based on the above discussion, it is worth noting that members' management review under Section 195 allows any shareholders with at least $10 \%$ of shareholders with voting power the opportunity to question, discuss, comment or make recommendations on the company's management. Nevertheless, the recommendation can only be binding if the resolution is passed via special resolution and such right to make a recommendation must be in is in the company's best interest, and most importantly, the matters shall be provided in the company's constitution. The principle is illustrated in Charterbridge Corp Ltd v Lloyds Bank Ltd [1970] Ch 62, where it was held that in assessing what is the best interest of the company is, the court would look at whether "whether an intelligent and honest man in the position of the director of the company concerned could in the whole of the existing circumstances have reasonably believed that the transactions were for the benefit of the company". This decision shows that the court will not interfere with the board's unfettered discretion in managing the company or otherwise also known as the business judgment rule. The barometer is that the court will not undertake to exercise the merits of a commercial business decision or business judgment by the directors. If the directors could prove such a decision is bona fide in the company's best interest, then the court will not encroach into their powers. It is argued that failure to uphold ESG reporting could not be deemed as non-compliance to this business judgement rule.

Despite having the power to request the board to convene a meeting under Section 311 of CA 2016, the matters to be discussed are usually about issues that the general meeting has power to pass, such as resolutions relating to issues solely within the powers of the board. Furthermore, the directors may apply to a court order under Section 325(1) to block the circulation of the statement or resolution if the court satisfies itself there is abuse by the requisition to secure needless publicity or has defamatory, frivolous or vexatious intentions and that their action is not in the best interest of the company.

Nevertheless, despite being the minority shareholders, the majority or controlling shareholders have, to some extent, owe a duty of care not to commit fraud on minority shareholders. Apart from the availability of statutory derivative action under Section 347 , the minority shareholders could also rely on the oppression remedy under Section 346, where they may apply to the court for an order to interfere if the majority shareholders disregard their interest or being oppressive to them. However, such a remedy is only available if the shareholders' interest is being prejudiced or disregarded or there were wrongs committed against the company by the directors. It is difficult to say whether the failure to promote ESG in the business practice tantamount to any breach of directors' statutory duty. The prospect of shareholders proposal to be successful in advancing the ESG-related agenda is higher if it is embedded in the statutes, either by incorporating the ESG-related principles in any of the provision like Indonesia or alternatively, incorporate it as a part of the company's constitution. By doing this, the BOD cannot turn away any ESG-related agenda during AGM. In comparison, Indonesian company laws mandate companies to consider activities to be based on sustainability, environmental awareness and community principles. Furthermore, Article $3 g$ of the European Union's Shareholders Directive 2017/828 also requires the institutional investors and asset managers to develop and publicly disclose an engagement policy that describes how they integrate shareholder engagement in their investment strategy (Directive (EU) 2017/828, 2017). These are the examples where the legal framework is ideal for promoting ESG among corporations by giving the opportunity to the shareholder activist to advocate ESG.

\subsection{Recommendations}

This paper suggests the minority shareholders should be empowered with authority to exert influence in corporations. For that, this paper has three (3) recommendations. Firstly, this paper suggests to the Malaysian legislators to incorporate ESG in the legal framework. The Malaysian Code for Institutional Investors stipulates that institutional investors shall include the corporate governance and sustainability considerations, including environmental, social and governance (ESG) factors in their investment decision-making process (Malaysian Code for Institutional Investors, 2014). However, it is not mandatory. In comparison, the Indonesian and EU counterparts have included the ESG-related provisions in their legal framework.

Secondly, this paper recommends that companies in Malaysia include ESG as one of the reserved matters that can be deliberated and discussed by shareholders. Section 31(2) of CA 2016 provides that each director and each member shall have the rights, powers, duties and obligations as set out in the Act unless modified by the constitution of the company. It means that if the shareholder activist intends to advance ESG in its agenda successfully, it has to be clearly provided in the company's constitution. By doing this, shareholders will have the opportunity to initiate shareholders proposal in the general meetings to discuss and deliberate on ESG.

Finally, this paper recommends that the minority shareholders be appointed as independent directors in the company. It is a generally accepted notion that independent directors play an essential role in monitoring the company's executives. The introduction of independent directors is to provide a check-and-balance mechanism against management control.

\subsection{Conclusion}

In conclusion, there is a growing trend by shareholders activist to advocates the discussion on ESG during general meetings. It is imperative that the corporate players in Malaysia, including institutional investors and shareholders activists, actively encourage the corporation to embrace ESG as one of its corporate goals. The spirit of shareholders activism must be reflected in the form of hard laws. This paper reckons future researchers to analyse the Malaysian legal framework and analyse if the legal framework could be reviewed 
by incorporating ESG like its Indonesian and EU counterpart. Ultimately, the shareholder's rights shall be strengthened to allow more voices by the minority shareholders in the decision-making process.

\section{Acknowledgement}

The authors thank the Faculty of Law, Universiti Teknologi MARA (UiTM) for their financial support by the Lex Praesta Research grant 600 -FUU-(PT. 5/2). The authors also thank the reviewers for their comments that have improved this paper. All errors are solely ours.

\section{Paper contribution to Related Field of Study}

This paper contributes to the growing academic discussion on strengthening the legal framework of the shareholder activism in promoting ESG in Malaysia.

\section{References}

Aquila, F. J. (Ed.). (2019). Chapter 14: United Kingdom. In The Shareholder Rights and Activism Review (p. 171). Law Business Research Ltd. www. TheLawReviews.co.uk

Aslan, H. (2020). Shareholders versus stakeholders in investor activism: Value for whom? Journal of Corporate Finance, 60(September 2018), 101548. https://doi.org/10.1016/j.jcorpfin.2019.101548

Atan, R., Alam, M. M., Said, J., \& Zamri, M. (2018). The impacts of environmental, social, and governance factors on firm performance: Panel study of Malaysian companies. Management of Environmental Quality: An International Journal, 29(2), 182-194. https://doi.org/10.1108/MEQ-03-2017-0033

Bainbridge, S. M. (2006). Director Primacy and Shareholder Disempowerment. Harvard Law Review, 119(6), 1735-1758.

Chan, J. C. H., \& Welford, R. (2005). Assessing corporate environmental risk in China: An evaluation of reporting activities of Hong Kong listed enterprises. Corporate Social Responsibility and Environmental Management, 12(2), 88-104. https://doi.org/10.1002/csr.88

Chung, H., \& Talaulicar, T. (2010). Forms and effects of shareholder activism. Corporate Governance: An International Review, 18(4), $253-257$. https://doi.org/10.1111/j.1467-8683.2010.00806.x

Dent, C. (2017). A Law Student-Oriented Taxonomy for Research in Law. Victoria University of Wellington Law Review., 2.

Directive (EU) 2017/828, Pub. L. No. Directive (EU) 2017/828, 2017 (2017).

Eddymurthy, I. A., \& Fakhry, S. R. (2020). Shareholder activism in Indonesia. https://uk.practicallaw.thomsonreuters.com/w-0130805?transitionType=Default\&contextData=(sc.Default)\&firstPage=true

Fairfax, L. M. (2019). Social Activism through Shareholder Activism. Washington and Lee Law Review, 76, 1129.

https://heinonline.org/HOL/Page?handle=hein.journals/waslee76\&id=1161\&div=28\&collection=journals

Kalodimos, J., \& Leavitt, K. (2020). Experimental Shareholder Activism: A novel approach for studying top management decision making and employee career issues Journal of Vocational Behavior, 120(May), 103429. https://doi.org/10.1016/j.jvb.2020.103429

Law No. 40 of 2007 Concerning Limited Liability Company, (2007). http://www.bkpm.go.id/file uploaded/Law_4199.htm Law No 25 of 2007 Concerning Investment, (2007). http://prokum.esdm.go.id/uu/2007/uu-30-2007-en.pdf

Lin, T. C. W. (2018). Incorporating Social Activism. Boston University Law Review, 98, 1535.

https://www.academia.edu/38922036/The Integration of Technology into English Language Teaching The Underlying Significance of LMS in ESL_Teaching de spite_the_Ebb_and_Flow_of_Implementation?email_work_card=view-paper\%250Ahttps://doi.org/10.1155/2016/3159805\%25

Lin, Y. H. (2019). When activists meet controlling shareholders in the shadow of the law: A case study of Hong Kong. Asian Journal of Comparative Law, 14(1), 1-36. https://doi.org/10.1017/asjcl.2019.12

Malaysian Code for Institutional Investors. (2014). MSWG \& SC.

Mohd-Sulaiman, A. N., \& Hassan, H. (2017). Shareholders ' Activism and their Power to Instruct. Pertanika Journal of Social Science and Humanities, 25, 11-24. MSWG. (2020). ESG : A matter of short-term pain , long-term gain (Issue December). https://mswg.org.my/sites/default/files/11 December 2020 MSWG Newsletter $\% 28$ final\%29.pdf

Nahar Abdullah, S. (2004). Board composition, CEO duality and performance among Malaysian listed companies. Corporate Governance: The International Journal of Business in Society, 4(4), 47-61. https://doi.org/10.1108/14720700410558871

PWC. (2020a). ESG oversight : The corporate director's quide (Issue November). https://www.pwc.com/us/en/services/governance-insights-center/esg-guidebooklayout-final.pdf

PWC. (2020b). Rethinking ESG in a post COVID-19 World. 
Rahman, L. (2021). Time for company directors to get serious about ESG. The Star Online. https://www.thestar.com.my/business/business-news/2021/01/22/time-forcompany-directors-to-get-serious-about-esg

Samat, N. H. A., \& Ali, H. M. (2019). Reviving shareholders' participation in companies' decision-making in Malaysia. Malaysian Journal of Consumer and Family Economics, 23(s1), 73-88.

Survei Nasional: Environmental Social Governance (ESG). (2019). 